\title{
Hematological and morphometric differences of blood cells from rheas, Rhea americana (Struthioniformes: Rheidae) on two conservation farms
}

\author{
S. S. M. Gallo ${ }^{a}$, N. B. Ederli ${ }^{b}$ and F. C. R. Oliveira* \\ ${ }^{a}$ Laboratório de Sanidade Animal, Universidade Estadual do Norte Fluminense Darcy Ribeiro - UENF, \\ Av. Alberto Lamego, 2000, CEP 28013-600, Campos dos Goytacazes, RJ, Brazil \\ bUniversidade Federal do Pará - UFPA, Campus Universitário do Marajó-Breves, Alameda IV, 3418, \\ CEP 68800-000, Breves, PA, Brazil \\ *e-mail: oliveirafcr@gmail.com
}

Received: May 17, 2015 - Accepted: January 20, 2016 - Distributed: May 31, 2017

\begin{abstract}
Today, blood tests are an indispensable tool in avian medicine. This study aimed to describe and compare hematological and morphometric data of erythrocytes, leukocytes and thrombocytes of rhea, Rhea americana. To do so, 58 rheas of both sexes on two farms, one in Cachoeiro do Itapemirim, Espírito Santo (ES), and the other in São Carlos, São Paulo (SP), were selected. Blood samples were taken and their RBC counts, PCV and $\mathrm{Hb}$ levels were determined and used in hematimetric index calculations. The total and differentiated leukocyte counts and the TPP and fibrinogen serum levels were also obtained. The results from the two farms analyzed were compared by means of the $t$ test. There were differences in the parameters of the erythrocyte series between the two flocks because of a process of hypochromic macrocytic anemia observed among the rheas in ES. The values for the erythrocyte series and indexes were: RBC, $2.81 \pm 0.15 \times 10^{6} / \mu \mathrm{l} ; \mathrm{PCV}, 44.20 \pm 2.86 \% ; \mathrm{Hb}, 12.12 \pm 0.74 \mathrm{~g} / \mathrm{dL} ; \mathrm{MCV}, 15.75 \pm 0.89 \mathrm{fL} ; \mathrm{MCH}, 43.18 \pm 1.82 \mathrm{pg} ;$ and MCHC, $27.44 \pm 0.80 \mathrm{~g} / \mathrm{dL}$. The values for the leukocyte series were: $\mathrm{WBC}, 12,072 \pm 4116 / \mu \mathrm{L}$; heterophils, $64.10 \pm 9.90 \%$; eosinophils, $2.05 \pm 2.06 \%$; monocytes, $6.40 \pm 2.99 \%$; lymphocytes, $26.93 \pm 9.62 \%$; and basophils, $0.52 \pm 1.27 \%$. These can all be suggested as references for rheas reared in Brazil. Statistical differences were observed in erythrocyte length measurements, which were higher in the rheas in SP than in those in ES. Regarding width, the heterophils, lymphocytes and monocytes of the birds in ES were statistically greater than those of the birds in SP. It was concluded that rheas may exhibit morphometric alterations to blood cells and differences in blood elements according to the type of management to which they are subjected.
\end{abstract}

Keywords: clinical pathology, blood tests, morphometry, ratites.

\section{Diferenças hematológicas e morfométricas de células sanguineas de emas, Rhea americana (Struthioniformes: Rheidae) em dois criatórios conservacionistas}

\section{Resumo}

Atualmente exames de sangue são ferramentas indispensáveis na medicina aviária. Este estudo teve como objetivo descrever e comparar valores hematológicos e morfométricos de eritrócitos, leucócitos e trombócitos de emas, Rhea americana. Para isso, foram selecionadas 58 emas de ambos os sexos de dois criatórios, um em Cachoeiro do Itapemirim, Espírito Santo (ES) e o outro em São Carlos, São Paulo (SP). Amostras de sangue foram coletadas e realizadas a hematimetria, Hto e dosagem de $\mathrm{Hb}$ que foram utilizados nos cálculos dos índices hematimétricos. Também foram efetuadas as contagens total e diferencial de leucócitos, além da dosagem de proteínas total e do fibrinogênio séricos. Os resultados referentes às duas propriedades analisadas foram comparados pelo Teste t. Ocorreram diferenças nos parâmetros da série vermelha entre as aves dos dois criatórios devido a um processo de anemia macrocítica hipocrômica observado nas emas do ES. Os valores para a série vermelha e índices hematimétricos como: hematimetria, 2,81 $\pm 0,15 \times 10^{6} / \mu 1$;

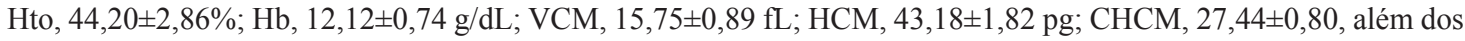
valores da série branca como: leucometria total, $12.072 \pm 4.116 / \mu \mathrm{L}$, heterofilo, $64,10 \pm 9,90 \%$, eosinófilo, 2,05 $\pm 2,06 \%$, monócito, $6,40 \pm 2,99 \%$, linfócito, $26,93 \pm 9,62 \%$, basófilo, $0,52 \pm 1,27 \%$ foram sugeridos como os de referência para as emas criadas no Brasil. Diferenças estatísticas foram observadas no comprimento de eritrócitos, o qual estava maior nas emas de SP do que aquelas do ES. Em relação à largura, os heterófilos, linfócitos e monócitos das aves do ES foram estatisticamente maior do que aquelas das aves de SP. Concluiu-se que emas podem apresentar alterações morfométricas de células sanguíneas e diferenças nos elementos do sangue de acordo com o tipo de manejo a que são submetidos.

Palavras-chave: patologia clínica, testes sanguíneos, morfometria, ratitas. 


\section{Introduction}

Rheas are birds belonging to the order Rheiformes, which comprises two known species, the Greater or Common Rhea, Rhea americana, and the Lesser or Darwin Rhea, Pterocnemia pennata, both from South America (Huchzermeyer, 2000). There is little information about the signs and symptoms of diseases of these birds, including hematological data on healthy individuals or changes that might support disease diagnoses (Charles Noriega, 2000).

Clinical signs in birds are very non-specific, and physical examinations provide limited information. Blood tests are an indispensable tool in bird medicine (Lumeij, 1997). In this context, the hematological data refer to cellular elements and their alterations, and also include quantitative and qualitative assessments of red and white blood cell series (Fudge, 2000) and morphological data relating to changes to cells. These data can assist clinicians in diagnosing various diseases and pathological conditions (Fudge, 2000).

Few data on the hematology of rheas, R. americana, are available. However, Chart 1 shows reference values for these birds at the adult stage of their development, except for thrombocytes values. These cells are present in reptiles, amphibians and fish, as well as in birds (Frye, 1991; Campbell, 1995; Jain et al., 2000; Veiga et al., 2000).

The present study aimed to describe and compare hematological and morphometric data of erythrocytes, leukocytes and thrombocytes of rhea, Rhea americana, of two conservationist farms in the States of Espírito Santo and São Paulo.

\section{Material and Methods}

Fifty-eight adult rheas of both sexes were used in this study. Forty-eight were from a conservation breeding program located in the municipality of Cachoeiro do Itapemirim $\left(20^{\circ} 50^{\prime} 58^{\prime \prime} \mathrm{S}, 41^{\circ} 6^{\prime} 48^{\prime \prime} \mathrm{W}\right)$ in the State of Espírito Santo (ES), and 10 were from an ecological park in the municipality of São Carlos $\left(22^{\circ} 0\right.$ ' 55"'S, $47^{\circ} 53^{\prime} 28^{\prime}$ 'W) in the State of São Paulo (SP), both in Brazil. Birds of State of Espírito Santo were raised in paddocks without grass and fed with commercial ration for ostriches, Struthio camelus, plus vegetables and chopped fruit in the trough twice a day. Birds of State of São Paulo were raised in paddocks with pasture of signal grass, Brachiaria decumbens, and ration formulated for rheas and water, ad libitum. Laboratory tests on the ES animals were done in the Clinical Pathology sector of the Veterinary Hospital of the Fluminense State University (UENF) and those on the SP animals were done at the Clinical Pathology Laboratory of the "Júlio de Mesquita Filho" São Paulo State University (UNESP), Jaboticabal campus. Morphometric analysis on the blood cells of all the birds was performed at the Advanced Parasitological Research Center (NUPAP) of the Bird Study and Research Unit (UEPA) of UENF.

The blood samples were collected by puncturing the brachial vein. The blood was drained into glass tubes containing EDTA, labeled and stored in a refrigerator until processing on the same day.

Total red blood cell (RBC) counts were performed using the MS4 ${ }^{\circledR}$ hematological cell counter (Melet Schloesing Laboratories, France) following the manufacturer's instructions. The packed cell volume (PCV) was determined by means of the microhematocrit method in capillary tubes, with centrifugation at $12,000 \mathrm{~g}$ for 5 minutes. The hemoglobin concentration $(\mathrm{Hb})$ was determined using the Labtest ${ }^{\circledR}$ reagent, with evaluation using a spectrophotometer (Biosystems ${ }^{\circledR}$ BTS 310) with the absorbance measured at $540 \mathrm{~nm}$. The $\mathrm{RBC}$ indices of mean corpuscular volume (MCV), mean corpuscular hemoglobin $(\mathrm{MCH})$ and mean corpuscular hemoglobin concentration (MCHC) were calculated using the results determined from the red fraction (Jain et al., 2000), and the values were expressed in femtoliters (fL), picograms (pg) and grams per deciliter (g/dL), respectively.

Chart 1. Hematological values of reference for adult rheas, Rhea americana.

\begin{tabular}{|c|c|c|c|c|}
\hline \multicolumn{2}{|c|}{ EVALUATED PARAMETERS } & \multirow{2}{*}{ UN ${ }^{1}$} & \multicolumn{2}{|c|}{ AUTHORS } \\
\cline { 2 - 5 } & & & Green (1999) & Fortes et al. (2009) \\
\cline { 2 - 5 } & $\mathrm{RBC}$ & $\mathrm{x} 10^{6} / \mu \mathrm{L}$ & $2.25 \pm 0.1$ & $2.39 \pm 0.52(1.60-2.90)$ \\
\cline { 2 - 5 } & $\mathrm{PCV}$ & $\%$ & $41.6 \pm 1.9$ & $39.6 \pm 5.48(30-45)$ \\
\cline { 2 - 5 } & $\mathrm{Hb}$ & $\mathrm{g} / \mathrm{dL}$ & $13.4 \pm 0.45$ & $16.27 \pm 4.40(9.40-26.00)$ \\
\cline { 2 - 5 } & $\mathrm{MVC}$ & $\mathrm{fL}$ & $18.5 \pm 5.9$ & $17.1 \pm 3.44(12.1-25)$ \\
\cline { 2 - 5 } & $\mathrm{MCH}$ & $\mathrm{pg}$ & $59.56^{*}$ & $70 \pm 19.70(43-99)$ \\
\cline { 2 - 5 } & $\mathrm{MCHC}$ & $\mathrm{g} / \mathrm{dL}$ & $32 \pm 0.01$ & $42.1 \pm 12.78(24-63)$ \\
\cline { 2 - 5 } & WBC & $/ \mu \mathrm{L}$ & $13600 \pm 3300$ & $8.683 \pm 4,860(3.000-18.500)$ \\
\cline { 2 - 5 } & Heterophils & $\%$ & $(59.5 \pm 33.3)^{*}$ & $62.09 \pm 8.58(52-78)$ \\
\cline { 2 - 5 } & Eosinophils & $\%$ & $(1.47 \pm 1.47)^{*}$ & $2.18 \pm 1.02(0.30-3.10)$ \\
\cline { 2 - 5 } & Monocytes & $\%$ & $(3.68 \pm 2.94)^{*}$ & $6.01 \pm 2.99(1.40-9.70)$ \\
\cline { 2 - 5 } & Lymphocytes & $\%$ & $(31.6 \pm 23.2)^{*}$ & $27.04 \pm 6.60(17.70-34.30)$ \\
\cline { 2 - 5 } & Basophils & $\%$ & & $2.69 \pm 1.43(1.00-6.00)$ \\
\hline
\end{tabular}

${ }^{1}$ Units of measurement; *Values calculated from authors data. 
Total white blood cell (WBC) counts were performed by means of a manual method using blood diluted in $0.01 \%$ toluidine blue stain (Blue-Mclendon and Green, 2010) and the results were expressed in units per microliter $(\mu \mathrm{L})$. Thin smears on glass slides were made immediately after the blood collection in order to avoid any interference with cell structures. Differential WBC counts, using an average of 200 cells, were made from blood films stained using Fast Panoptic method and were examined under an optical microscope with a 100x objective (in immersion oil).

For the morphometric analysis, stained smears were analyzed under a microscope and the images were captured using a digital camera (Canon PowerShot A640) with the aid of a computer and the Zeiss Axion Vision software. Erythrocytes, leukocytes and thrombocytes were identified and their lengths and widths were measured (1000x magnification). In all animals was analyzed one blood film and five cells of each type were measured per blood film.

Fibrinogen was measured by means of the capillary method after denaturation of the total plasma protein (TPP) to $56^{\circ} \mathrm{C}$ for 3 minutes with reading of both capillaries in a refractometer. The values were expressed in $\mathrm{mg} / \mathrm{dL}$ and $\mathrm{g} / \mathrm{dL}$, respectively.

To calculate central trend values and compare the mean lengths and widths of the cells and thrombocytes present in the rheas' blood, and also to perform quantitative analysis on the blood components of these birds in relation to the two farms investigated, Student's $t$ test with $5 \%$ significance was used. All of the calculations were performed using the SAEG software (Statistical Analysis System, version 9.1).

\section{Results}

The total number of sampled collected was 58 , but two of them had hemolysis problems and another sample coagulated and could not be analyzed to quantify erythrocytes in the $\mathrm{MS} 4{ }^{\circledast}$ erythrocyte counter. On the other hand, PCV and $\mathrm{Hb}$ were measured in relation to the samples with hemolysis problems (Table 1). Concerning WBC counts, 16 samples had staining problems on examination in a Neubauer chamber. These results were deemed unreliable and were therefore discarded (Table 1).

The samples from the animals in the ES conservation breeding program were also evaluated regarding the parameters of total protein and fibrinogen. However, no basophils were observed in the blood smears (Table 1). Among the 10 rheas reared at the ecological park in São Carlos, only the hematological parameters shown in Table 2 were measured. The hematological values for the rheas on the two farms were compared by means of the $t$ test. It was not possible to compare basophils, since these cells were not observed in the blood from the birds on the ES farm (Table 3).

Total protein values were assessed in the serum of the birds on the ES farm (Table 1). However, two samples were discarded because of lack of reliability in the results. It was not possible to compare these parameters between the farms evaluated, since they were not measured in the serum of the SP birds (Table 3). Thus, the total number of samples was 46 (Table 1).

The blood cells of rheas reared in ES (Table 4) and SP (Table 5) were measured separately. Statistical differences in length measurements on the blood cells from the rheas on the two farms were observed, such

Table 1. Hematological values of rheas, Rhea americana, reared in captivity in a conservationist farm in the municipality of Cachoeiro do Itapemirim-ES, Brazil.

\begin{tabular}{|c|c|c|c|c|c|c|c|}
\hline \multirow{2}{*}{\multicolumn{2}{|c|}{ Evaluated parameters }} & \multirow{2}{*}{$\mathbf{U N}^{1}$} & \multirow{2}{*}{$\mathbf{n}^{2}$} & \multirow{2}{*}{ Mean } & \multirow{2}{*}{$\begin{array}{l}\text { Standard } \\
\text { deviation }\end{array}$} & \multicolumn{2}{|c|}{ Range of Values } \\
\hline & & & & & & Minimum & Maximum \\
\hline \multirow{6}{*}{ Red fraction } & RBC & $\mathrm{x} 10^{6} / \mu 1$ & $45^{3}$ & 0.86 & 0.27 & 0.29 & 1.42 \\
\hline & PCV & $\%$ & $46^{4}$ & 40.04 & 4.43 & 31 & 51 \\
\hline & $\mathrm{Hb}$ & $g / d L$ & 46 & 10.07 & 1.22 & 7.80 & 12.40 \\
\hline & MVC & $\mathrm{fL}$ & 45 & 51.15 & 16.20 & 27.46 & 106.90 \\
\hline & $\mathrm{MCH}$ & pg & 45 & 129.16 & 45.44 & 67.24 & 286.21 \\
\hline & $\mathrm{MCHC}$ & $g / d L$ & 46 & 25.25 & 2.57 & 18.18 & 33.05 \\
\hline \multirow{6}{*}{ White fraction } & WBC & $/ \mu \mathrm{L}$ & $32^{5}$ & 11.720 & 4.090 & 5.350 & 24.400 \\
\hline & Heterophils & $\%$ & 48 & 64.10 & 10.52 & 37 & 88 \\
\hline & Eosinophils & $\%$ & 48 & 2.12 & 2.23 & 0 & 10 \\
\hline & Monocytes & $\%$ & 48 & 6.21 & 3.02 & 0 & 15 \\
\hline & Lymphocytes & $\%$ & 48 & 27.56 & 10.19 & 6 & 50 \\
\hline & Basophils & $\%$ & 0 & 0 & 0 & 0 & 0 \\
\hline \multirow{2}{*}{ Protein } & TPP & $\mathrm{g} / \mathrm{dL}$ & $46^{6}$ & 6.41 & 0.95 & 4.60 & 9.20 \\
\hline & Fibrinogen & $\mathrm{mg} / \mathrm{dL}$ & 46 & 297.83 & 249.88 & 100 & 1.400 \\
\hline
\end{tabular}

${ }^{1}$ Units of measurement; ${ }^{2}$ Number of samples; ${ }^{3}$ From the 48 samples collected three were not analyzed, two due to hemolysis problems and one due to clotting; ${ }^{4}$ From the 48 samples collected, two that had hemolysis were not analyzed; ${ }^{5}$ Problems with staining and observation of the cell morphology in Neubauer chamber led to the discard of 16 samples; ${ }^{6}$ Two samples were not analyzed in this property because of lack of trust in the results. 
Table 2. Hematological values of rheas, Rhea americana, reared in captivity in a Ecological Park in the municipality of São Carlos-SP, Brazil.

\begin{tabular}{|c|c|c|c|c|c|c|c|}
\hline \multirow{2}{*}{\multicolumn{2}{|c|}{ Evaluated parameters }} & \multirow{2}{*}{$\mathbf{U N}^{1}$} & \multirow{2}{*}{$n^{2}$} & \multirow{2}{*}{ Mean } & \multirow{2}{*}{$\begin{array}{l}\text { Standard } \\
\text { deviation }\end{array}$} & \multicolumn{2}{|c|}{ Range of Values } \\
\hline & & & & & & Minimum & Maximum \\
\hline \multirow{6}{*}{ Red fraction } & $\mathrm{RBC}$ & $\mathrm{x} 10^{6} / \mu 1$ & 10 & 2.81 & 0.15 & 2.60 & 3.10 \\
\hline & PCV & $\%$ & 10 & 44.20 & 2.86 & 39 & 49 \\
\hline & $\mathrm{Hb}$ & $\mathrm{g} / \mathrm{dL}$ & 10 & 12.12 & 0.74 & 10.59 & 13.33 \\
\hline & MVC & $\mathrm{fL}$ & 10 & 15.75 & 0.89 & 14.48 & 17.41 \\
\hline & $\mathrm{MCH}$ & pg & 10 & 43.18 & 1.82 & 40.73 & 46.03 \\
\hline & $\mathrm{MCHC}$ & $\mathrm{g} / \mathrm{dL}$ & 10 & 27.44 & 0.80 & 26.23 & 28.64 \\
\hline \multirow{6}{*}{ White fraction } & WBC & $/ \mu \mathrm{L}$ & 10 & 13.200 & 4.211 & 7.000 & 21.000 \\
\hline & Heterophils & $\%$ & 10 & 64.10 & 6.54 & 55 & 75 \\
\hline & Eosinophils & $\%$ & 10 & 1.70 & 0.95 & 1 & 4 \\
\hline & Monocytes & $\%$ & 10 & 7.30 & 2.83 & 3 & 12 \\
\hline & Lymphocytes & $\%$ & 10 & 23.90 & 5.66 & 18 & 32 \\
\hline & Basophils & $\%$ & 10 & 3.00 & 1.41 & 1 & 6 \\
\hline
\end{tabular}

${ }^{1}$ Units of measurement; ${ }^{2}$ Number of samples.

Table 3. Comparison of hematologic values by $5 \% \mathrm{t}$ test of rheas, Rhea americana, reared in captivity in two different systems of feed management.

\begin{tabular}{|c|c|c|c|c|c|c|c|c|}
\hline \multirow{2}{*}{\multicolumn{2}{|c|}{ Evaluated parameters }} & \multirow[b]{2}{*}{$\mathbf{U} \mathbf{N}^{1}$} & \multicolumn{4}{|c|}{ FARMS } & \multirow[b]{2}{*}{ F Test } & \multirow[b]{2}{*}{ P Value } \\
\hline & & & $n^{2}$ & $\begin{array}{l}\text { Espírito } \\
\text { Santo }^{4}\end{array}$ & $\mathbf{n}$ & São Paulo ${ }^{5}$ & & \\
\hline \multirow{6}{*}{ Red fraction } & $\mathrm{RBC}$ & $\mathrm{x} 10^{6} / \mu \mathrm{l}$ & 45 & $0.86 \pm 0.27$ & 10 & $2.81 \pm 0.15$ & 3.148 & $<0.001$ \\
\hline & PCV & $\%$ & 46 & $40.04 \pm 4.43$ & 10 & $44.20 \pm 2.86$ & 2.402 & 0.006 \\
\hline & $\mathrm{Hb}$ & $\mathrm{g} / \mathrm{dL}$ & 46 & $10.07 \pm 1.22$ & 10 & $12.12 \pm 0.74$ & 2.693 & $<0.001$ \\
\hline & MVC & $\mathrm{fL}$ & 45 & $51.15 \pm 16.20$ & 10 & $15.75 \pm 0.89$ & 332.7 & $<0.001$ \\
\hline & $\mathrm{MCH}$ & pg & 45 & $129.16 \pm 45.44$ & 10 & $43.18 \pm 1.82$ & 620.3 & $<0.001$ \\
\hline & $\mathrm{MCHC}$ & $\mathrm{g} / \mathrm{dL}$ & 45 & $25.25 \pm 2.67$ & 10 & $27.44 \pm 0.80$ & 10.29 & 0.010 \\
\hline \multirow{6}{*}{ White fraction } & WBC & $/ \mu \mathrm{L}$ & 32 & $11720 \pm 4090$ & 10 & $13200 \pm 4211$ & 1.06 & 0.327 \\
\hline & Heterophils & $\%$ & 48 & $64.10 \pm 10.52$ & 10 & $64.10 \pm 6.54$ & 2.58 & 1.000 \\
\hline & Eosinophils & $\%$ & 48 & $2.12 \pm 2.23$ & 10 & $1.70 \pm 0.95$ & 5.51 & 0.558 \\
\hline & Monocytes & $\%$ & 48 & $6.21 \pm 3.02$ & 10 & $7.30 \pm 2.83$ & 1.14 & 0.298 \\
\hline & Lymphocytes & $\%$ & 48 & $28.56 \pm 10.19$ & 10 & $23.90 \pm 5.67$ & 3.23 & 0.277 \\
\hline & Basophils & $\%$ & $\mathrm{NM}^{3}$ & NM & NM & NM & NM & $\mathrm{NM}$ \\
\hline \multirow{2}{*}{ Protein } & TPP & $\mathrm{g} / \mathrm{dL}$ & $\mathrm{NM}$ & NM & $\mathrm{NM}$ & $\mathrm{NM}$ & NM & $\mathrm{NM}$ \\
\hline & Fibrinogen & $\mathrm{mg} / \mathrm{dL}$ & NM & $\mathrm{NM}$ & $\mathrm{NM}$ & $\mathrm{NM}$ & $\mathrm{NM}$ & $\mathrm{NM}$ \\
\hline
\end{tabular}

${ }^{1}$ Units of measurement; ${ }^{2}$ Number of samples; ${ }^{3}$ Not mesured; ${ }^{4}$ Birds raised in paddocks without grass and fed with commercial ration for ostriches, Struthio camelus, plus vegetables and chopped fruit in the trough twice a day; ${ }^{5}$ Birds raised in paddocks with pasture of signal grass, Brachiaria decumbens, and ration formulated for rheas, Rhea americana ad libitum.

Table 4. Morphometry of blood cells of rheas, Rhea americana, reared in captivity in the Espírito Santo, Brazil.

\begin{tabular}{|c|c|c|c|c|}
\hline \multirow{2}{*}{ Blood Cells } & \multirow{2}{*}{$\mathbf{n}^{1}$} & \multicolumn{2}{|c|}{ Measurements in micrometers } & \multirow{2}{*}{$\begin{array}{c}\text { Morphometric } \\
\text { Index } \\
\end{array}$} \\
\hline & & Length & Width & \\
\hline Erythrocytes & 240 & $13.89 \pm 1.00(11.15-17.00)$ & $8.51 \pm 0.94(1.87-12.35)$ & $1.66 \pm 0.41(1.05-7.28)$ \\
\hline Heterophils & 239 & $13.12 \pm 1.56(9.73-20.24)$ & $11.64 \pm 1.28(7.92-15.15)$ & $1.13 \pm 0.14(1.00-2.26)$ \\
\hline Eosinophils & 289 & $13.15 \pm 1.65(8.95-19.29)$ & $11.23 \pm 1.31(7.73-15.32)$ & $1.18 \pm 0.17(1.00-2.28)$ \\
\hline Monocytes & 223 & $16.19 \pm 2.40(11.14-24.47)$ & $13.81 \pm 2.08(9.06-21.02)$ & $1.18 \pm 0.15(1.00-1.70)$ \\
\hline Lymphocytes & 240 & $8.87 \pm 2.00(5.69-16.34)$ & $7.53 \pm 1.74(4.41-13.25)$ & $1.19 \pm 0.17(1.00-1.99)$ \\
\hline Basophils & - & - & - & - \\
\hline Thrombocytes & 240 & $8.55 \pm 1.53(5.46-13.96)$ & $6.75 \pm 1.33(3.54-10.69)$ & $1.29 \pm 0.25(1.00-2.50)$ \\
\hline
\end{tabular}

${ }^{1}$ Number of cells, considering, at least, five cells of each type per smear. 
that the erythrocytes were longer in SP than in ES, but this was not observed with regard to leukocytes and thrombocytes (Table 6).

The blood cells from the birds in ES were wider than those from birds in SP, with statistical differences in relation to heterophils, lymphocytes and monocytes (Table 7). The differences in the lengths and widths of the blood cells from the rheas on the two farms evaluated resulted in differences in morphometric index (MI) regarding heterophils and monocytes (Table 8).

Table 5. Morphometry of blood cells of rheas, Rhea americana, reared in captivity in São Paulo, Brazil.

\begin{tabular}{|c|c|c|c|c|}
\hline \multirow{2}{*}{ Blood Cells } & \multirow{2}{*}{$\mathrm{n}^{1}$} & \multicolumn{2}{|c|}{ Measurements in micrometers } & \multirow{2}{*}{$\begin{array}{c}\text { Morphometric } \\
\text { Index }\end{array}$} \\
\hline & & Length & Width & \\
\hline Erythrocytes & 50 & $14.67 \pm 1.01(12.71-16.73)$ & $8.29 \pm 0.60(6.96-9.53)$ & $1.78 \pm 0.19(1.42-2.28)$ \\
\hline Heterophils & 50 & $11.99 \pm 1.28(9.04-15.09)$ & $11.17 \pm 1.09(8.90-13.27)$ & $1.07 \pm 0.07(1.00-1.41)$ \\
\hline Eosinophils & 42 & $12.51 \pm 1.75(10.10-17.62)$ & $10.81 \pm 1.49(7.79-15.27)$ & $1.17 \pm 0.19(1.00-1.87)$ \\
\hline Monocytes & 50 & $13.08 \pm 2.11(7.14-19.23)$ & $12.11 \pm 1.97(7.04-17.50)$ & $1.08 \pm 0.07(1.00-1.32)$ \\
\hline Lymphocytes & 50 & $8.00 \pm 1.26(6.05-11.90)$ & $7.01 \pm 1.06(5.22-9.69)$ & $1.15 \pm 0.13(1.00-1.52)$ \\
\hline Basophils & 50 & $11.49 \pm 1.25(8.96-14.75)$ & $10.32 \pm 1.06(8.23-13.26)$ & $1.11 \pm 0.09(1.01-1.39)$ \\
\hline Thrombocytes & 50 & $8.01 \pm 1.09(5.60-10.17)$ & $6.43 \pm 1.20(4.38-9.24)$ & $1.27 \pm 0.23(1.01-2.09)$ \\
\hline
\end{tabular}

${ }^{1}$ Number of cells, taking into consideration whenever possible, five cells of each type per smear.

Table 6. Morphometric comparison of length in micrometers of blood cells of rheas, Rhea americana, reared in captivity in Brazil with two feed management systems by $5 \%$ t test.

\begin{tabular}{|c|c|c|c|c|c|c|}
\hline \multirow{2}{*}{ Blood Cells } & \multicolumn{4}{|c|}{ FARMS } & \multirow{2}{*}{ F Test } & \multirow{2}{*}{ P Value } \\
\hline & $n^{1}$ & Espírito Santo & n & São Paulo & & \\
\hline Erythrocytes & 240 & $13.89 \pm 1.00$ & 50 & $14.67 \pm 1.01$ & 1.020 & 0.0002 \\
\hline Heterophils & 239 & $13.12 \pm 1.56$ & 50 & $11.99 \pm 1.28$ & 1.480 & 0.0002 \\
\hline Eosinophils & 189 & $13.15 \pm 1.65$ & 42 & $12.51 \pm 1.75$ & 1.117 & 0.0246 \\
\hline Monocytes & 223 & $16.19 \pm 2.40$ & 50 & $13.08 \pm 2.11$ & 1.299 & 0.0002 \\
\hline Lymphocytes & 240 & $8.87 \pm 2.00$ & 50 & $8.00 \pm 1.26$ & 2.521 & 0.0031 \\
\hline Basophils & - & - & - & - & - & - \\
\hline Thrombocytes & 240 & $8.55 \pm 1.53$ & 50 & $8.01 \pm 1.09$ & 1.986 & 0.0182 \\
\hline
\end{tabular}

${ }^{1}$ Number of cells, taking into consideration whenever possible, five cells of each type per smear.

Table 7. Morphometric comparison of width in micrometers of blood cells of rheas, Rhea americana, reared in captivity in Brazil with two feed management systems by $5 \% \mathrm{t}$ test.

\begin{tabular}{|c|c|c|c|c|c|c|}
\hline \multirow{2}{*}{ Blood Cells } & \multicolumn{4}{|c|}{ FARMS } & \multirow{2}{*}{ F Test } & \multirow{2}{*}{ P Value } \\
\hline & $n^{1}$ & Espírito Santo & n & São Paulo & & \\
\hline Erythrocytes & 240 & $8.51 \pm 0.94$ & 50 & $8.29 \pm 0.60$ & 2.465 & 0.1105 \\
\hline Heterophils & 239 & $11.64 \pm 1.29$ & 50 & $11.17 \pm 1.09$ & 1.388 & 0.0173 \\
\hline Eosinophils & 189 & $11.23 \pm 1.31$ & 42 & $10.81 \pm 1.39$ & 1.285 & 0.0678 \\
\hline Monocytes & 223 & $13.81 \pm 2.08$ & 50 & $12.11 \pm 1.97$ & 1.113 & 0.0002 \\
\hline Lymphocytes & 240 & $7.53 \pm 1.74$ & 50 & $7.01 \pm 1.06$ & 2.716 & 0.0434 \\
\hline Basophils & - & - & - & - & - & - \\
\hline Thrombocytes & 240 & $6.75 \pm 1.33$ & 50 & $6.43 \pm 1.20$ & 1.237 & 0.1127 \\
\hline
\end{tabular}

${ }^{1}$ Number of cells, taking into consideration whenever possible, five cells of each type per smear.

Table 8. Morphometric comparison of morphometric index in micrometers of blood cells of rheas, Rhea americana, reared in captivity in Brazil with two feed management systems by $5 \% \mathrm{t}$ test.

\begin{tabular}{|c|c|c|c|c|c|c|}
\hline \multirow{2}{*}{ Blood Cells } & \multicolumn{4}{|c|}{ FARMS } & \multirow{2}{*}{ F Test } & \multirow{2}{*}{ P Value } \\
\hline & $n^{1}$ & Espírito Santo & $n$ & São Paulo & & \\
\hline Erythrocytes & 240 & $1.66 \pm 0.41$ & 50 & $1.78 \pm 0.19$ & 4.756 & 0.0531 \\
\hline Heterophils & 239 & $1.13 \pm 0.14$ & 50 & $1.07 \pm 0.07$ & 3.928 & 0.0035 \\
\hline Eosinophils & 189 & $1.18 \pm 0.17$ & 42 & $1.17 \pm 0.19$ & 1.308 & 0.7413 \\
\hline Monocytes & 223 & $1.18 \pm 0.15$ & 50 & $1.08 \pm 0.07$ & 3.886 & 0.0002 \\
\hline Lymphocytes & 240 & $1.19 \pm 0.17$ & 50 & $1.15 \pm 0.13$ & 1.922 & 0.0839 \\
\hline Basophils & - & - & - & - & - & - \\
\hline Thrombocytes & 240 & $1.29 \pm 0.25$ & 50 & $1.27 \pm 0.23$ & 1.145 & 0.6362 \\
\hline
\end{tabular}

${ }^{1}$ Number of cells, taking into consideration whenever possible, five cells of each type per smear. 


\section{Discussion}

Evaluation of rheas' blood components with the purpose of determining the hematological parameters of birds kept in captivity is hampered by the small number of farms that exist and by restrictions imposed by the farms, given the stress that these birds suffer during the collection procedure. This may be the reason why few studies have been conducted. Moreover, the small numbers that have been conducted have generally only evaluated small numbers of birds (Green, 1999; Fortes et al., 2009).

Low values for the erythrocyte series were observed among the birds in ES (Table 1). These same parameters evaluated among the birds in SP (Table 2) were within the normal range according to the references values in Green (1999). Since there were statistical differences between birds raised on farms in ES and SP (Table 3), it can be inferred that the birds in ES were becoming anemic. From the erythrocyte series values for the ES birds (Table 1), it appears that the anemia observed on the farm was the hypochromic macrocytic type. This type of anemia in birds is characteristic of nutritional deficiency or malabsorption, particularly of vitamin B and iron (Faria et al., 2009). There were statistical differences in the hematological parameters of the erythrocyte series between the birds reared in SP and ES. The birds in ES also presented a state of nutritional deficiency, which can be explained by inadequate management such that these birds had no access to grass and were fed with concentrate consisting of feedstuff for ostriches.

The results regarding the leukocyte series on the farms in ES and SP (Table 1 and 2) were within the normal range for the species (Green, 1999) and also did not differ statistically when compared (Table 3 ). These data indicate that the birds did not present any infectious or parasitic diseases capable of interfering in the parameters evaluated. This emphasizes the view that the abnormalities observed regarding the erythrocyte series among the rheas in ES were caused by problems in the feed management of these birds. Thus, the data relating to the leukocyte series for the birds on the two farms can be considered to be reference values for rheas reared in Brazil, as can the results relating to the erythrocyte series for the rheas in SP.

Contrary to what might have been expected in relation to the nutritional status of the birds reared in ES, it was observed that the measured protein values were higher than those cited as a reference by Kaneko et al. (1997), for birds (Table 1). It can therefore be assumed that the nutritional deficiencies of these birds were related to vitamin and mineral deficiencies and not to deficiencies of protein intake, given that the amount of protein offered in ostrich feed must also be suitable for rheas. This could be better assessed if the protein values of rheas in SP were also measured $\backslash$ High protein levels have been found in severe inflammatory processes in birds (Charles Noriega, 2000) and factors such as age, seasonality and disease can also influence protein values (Lumeij, 1997). However, from the findings of the present study, these factors did not influence the higher protein levels in the rheas in ES.
Morphometrically, it was observed that the mean erythrocyte values measured on the farms in ES and SP (Tables 4 and 5) were within the parameters observed by Benez (2001) for birds in general. There was even agreement with this author that these cells are larger in the order Rheiformes (Table 4, 5 and 6), such that it was observed that some erythrocytes reached $17 \mu \mathrm{m}$ in length and $12.35 \mu \mathrm{m}$ in width, in comparison with ranges of 11 to $16 \mu \mathrm{m}$ in length and 6 to $10 \mu \mathrm{m}$ in width observed by this author for birds in general.

It was observed that the shape of the erythrocytes of the birds in ES was normal, although there were different sizes, as characterized by great variation in the highest and lowest length and width measurements for the erythrocytes of these birds (Table 5). Contrary to what might have been predicted for the erythrocytes of the birds in ES from their characteristic macrocytic anemia, it was observed that the erythrocyte length among these rheas was statistically less than among the birds in SP (Table 6), which did not have anemia. This can be explained by the greater width found in the erythrocytes of the birds in ES: although this difference was not significant (Table 7), it may have compensated for the shorter cell length. Thus, evaluation of $\mathrm{RBC}$ indices (MCV, MCH and $\mathrm{MCHC}$ ) is more reliable for evaluating anemia relating to cell size in rheas than is morphometry alone.

Comparison of the shapes of the leukocyte series of the rheas between those in ES and in SP showed that the birds in SP had white blood cells that were more rounded, including a statistical difference in morphometric index with regard to heterophils and monocytes (Table 8).

Separate morphometric analyses on the white blood cells of the rheas reared in the states of ES and SP showed that the length and width measurements were also larger than those reported in the literature for birds in general and that some cells were of sizes within the range of measurements for birds (Lucas and Jamroz, 1961; Nirmalan et al., 1972; Campbell and Dein, 1984; Banks, 1993; Coles et al., 1998; Jain et al., 2000). Comparative morphometric analysis on these cells between rheas reared in ES and in SP showed that the leukocytes of the birds in ES had greater length and width than those in SP, except for the widths of eosinophils, which were not statistically different. This was also observed in relation to thrombocytes (Tables 6 and 7).

It is known that younger leukocytes are smaller and are more present in cell immune responses (Sharma, 1984). However, this does not explain the observed difference. It might be said that because the rheas in SP were nutritionally better, their immunological system was more active and had constant cell responses. Alternatively, the stress of the managerial and nutritional deficiency observed in the rheas in ES may have inhibited the cell immune response, thereby making older leukocytes remain in circulation in order to maintain the numbers of cells that were physiologically sufficient for a satisfactory cell immune response. This hypothesis is reinforced by the normality of the hematological values of the leukocyte series that were observed among the rheas in both localities. 


\section{Conclusion}

Rheas may show morphometric alterations to blood cells and differences in blood elements according to the type of management to which they are subjected. These differences are best shown through hematological parameters, which should be noted in comparison with results in the literature. The observed alterations to the erythrocyte series among the rheas in ES, which were characteristic of hypochromic macrocytic anemia, led to the inference that these birds reared in captivity needed to receive food that was appropriate for the species. Attempts to adapt formulated feedstuffs, even those formulated for other birds, including other ratites, can influence the hematological parameters of these birds, especially those relating to the erythrocyte series.

\section{References}

BANKS, W.J., 1993. Applied veterinary histology. 3rd ed. Baltimore: Mosby-Year Book. 527 p.

BENEZ, S.M., 2001. Aves: criação, clínica, teoria, prática. Silvestres, ornamentais, avinhados. 3rd ed. São Paulo: Robe. 522 p.

BLUE-MCLENDON, A. and GREEN, RA., 2010. Hematology of ratites. In: D.J. WEISS and K.J. WARDROP, eds. Schalm's veterinary hematology. 6th ed. Ames: Lippincott Williams \& Wilkins, pp. 987-993.

CAMPBELL, T.W. and DEIN, F.J., 1984. Avian hematology. The basics. Veterinary Clinics: Small Animal Practice, vol. 14, no. 2, pp. 223-248. PMid:6610969.

CAMPBELL, T.W., 1995. Avian hematology and cytology. 2nd ed. Ames: University Press. 104 p.

CHARLES NORIEGA, M.L.V.C., 2000. Apuntes de hematología aviar: material didático para curso de hematologia aviária. Aves: Universidad Nacional Autónoma de México. 70 p. Apostila mimeo.

COLES, B.H., KRAUTWALD-JUNHANNS, M.E. and HERRMAN, T.J., 1998. Self-assessment picture tests: avian medicine. St. Louis: Mosby. 212 p.

FARIA, D.E., JUNQUEIRA, O.M. and DUARTE, K.F., 2009. Enfermidades nutricionais. In: A. BERCHIERI JÚNIOR, E.N. SILVA, J.D. FÁBIO, L. SESTI and M.A.F. ZUANAZE. Doenças das aves. 2nd ed. Campinas: Fundação APINCO de Ciência e Tecnologia Avícolas, pp. 927-971.
FORTES, E.A.M., SOUSA, A.F., ALMEIDA, E.C.S., CONDE JÚNIOR, A.M. and MOURA, W.L., 2009. Morfologia das células do sangue periférico em emas (Rhea americana). Brazilian Journal of Veterinary Research and Animal Science, vol. 46, no. 3 , pp. $215-221$

FRYE, F.L., 1991. Biomedical and surgical aspects of captive reptile husbandry. 2nd ed. Melbourne: Krieger Publishing Company, vol. 1-2, $635 \mathrm{p}$.

FUDGE, A.M., 2000. Avian complete blood count. In A.M. FUDGE, ed. Laboratory medicine - avian and exotic pets. Philadelphia: W.B. Saunders, pp. 9-18.

GREEN, R.A., 1999. Reference range for normal ostriches and rheas. In: D.J. WEISS and K.J. WARDROP. Schalm's veterinary hematology. 6th ed. Ames: Lippincott Williams \& Wilkins, pp. 987-993.

HUCHZERMEYER, F.W., 2000. Doenças de avestruzes e outras ratitas. 2nd ed. Jaboticabal: Funep. 392 p.

JAIN, N.C., FELDMAN, B.F. and ZINKL, J.G., 2000. Schalm's veterinary hematology. 5th ed. Philadelphia: Lea \& Febiger. 538 p.

KANEKO, J.J., HARVEY, J.W. and BRUSS, M.L., 1997. Clinical biochemistry of domestic animals. 5th ed. SanDiego: Academic Press. 932 p.

LUCAS, A.M. and JAMROZ, C., 1961. Atlas of avian hematology. Washington: Department of Agriculture. $271 \mathrm{p}$.

LUMEIJ, J.T., 1997. Avian clinical biochemistry. In J.J. KANEKO, J.W. HARVEY and M.L. BRUSS. Clinical biochemistry of domestic animals. 5th ed. San Diego: Academic Press. 932 p.

NIRMALAN, G.P., ATWAL, O.S. and CARLSON, H.C., 1972. Ultra structural studies on leukocytes and thrombocytes in circulating blood of japanese-quail. Poultry Science, vol. 51, no. 6, pp. 2050-2055. http://dx.doi.org/10.3382/ps.0512050. PMid:4660986.

SHARMA, J.M., 1984. Effected of infectious bursal disease virus on protection against Marek's disease by turkey herpesvirus vaccine. Avian Diseases, vol. 28, no. 3, pp. 629-640. http://dx.doi. org/10.2307/1590231. PMid:6091603.

VEIGA, M.L., EGAMI, M.I., RANZANIPAIVA, M.J.T., RODRIGUES, E.L., 2000. Aspectos morfológicos y histoquímicos de las células sanguíneas de Salminus maxillosus Valenciennes, 1844 (Characiformes, Characidae). Revista Chilena de Anatomía, vol. 8 , pp. 245-250. 